\title{
The Impact of Zakat on Economic Growth in 5 State in Indonesia
}

\author{
Eko Suprayitno \\ Faculty of Economics, UIN Maulana Malik Ibrahim Malang, Indonesia \\ E-mail: suprayitno@pbs.uin-malang.ac.id
}

\begin{abstract}
This study aims to reveal the impact of zakat distribution on macroeconomic in 5 state In Indonesia, by using ECM analysis. The motivation of the current research lies on the belief of a large number of economists that zakat does not affect macro economy because 2.5 percent is perceived insignificant. This issue leads to a high curiosity about the impact of zakat distribution in Indonesia. This study finds that zakat has a significant and positive relationship with economic growth. The results of the ECM analysis show that the distribution of zakat positively influences on economic growth. The long-run elasticity of zakat variable is positive and significant.
\end{abstract}

Keywords: Zakat, Economic Growth, Consumption.

\section{Introduction}

As a socio-economic institution founded in the 7th century, zakah is the first fiscal system in the world, which has a remarkable completeness of rules, from the subject of zakat payments, the object of zakat property and its respective tariffs, the limit of minimum wealth (Nisab), the period of ownership (haul), to the allocation of the distribution (mustahik). If applied systematically in the economy, especially the rule-based one and the Compellent Islamic spirit, zakat will also have important and significant economic characteristics and implications that leads to a great social building.

In economy, zakat has a broad meaning in both macro and micro scale. Zakat in macroeconomy can be a fiscal policy instrument in a country or a public sphere of Islam while that in micro-economy can play an essential role in the allocation or distribution of zakat to the recipient. Al-Qur'an, at-Taubah verse 60, determines the eligible group of people to receive zakat, some of which are the poor and the needy. They will get the share of zakat as a process of the income distribution.

In Indonesia, Under the Law No. 38/1999 states that zakat paid to BAZ or LAZ can be deducted from the taxable profit or income of a taxpayer according to current tax regulation. On the other hand, Law No. 17/2000, the current tax regulation, does not include zakat among the listed deductions. Instead, this Law indicates that zakat collected by BAZ or LAZ cannot be counted as a deduction in determining the amount of income subject to tax.

This conflict has been partly solved through issuance of Tax Decision No. KEP-I63/PJ/2003 by the Director General of Tax. Article I sections I and 3 of the Decision state that zakat paid to BAZ or official LAZ may be subtracted from the gross income of a taxpaying legal body or from the net income of a personal taxpayer up to $2.5 \% .60$ But this deduction is limited to income subject to both zakat and income tax. Because the category of zakatable items is broader than the items subject to income tax,6I some zakat, such as that on wealth, will not be deductible.

The problem of zakat is not only in the process of collection. It also lies in distribution. Zakat is even critical today. Al-Qur'an gives more guidance on the distribution of zakat compared to the collection. However, the most important problem is the implication of the distribution of zakat to the asnaf. Most researches merely consider the influence of zakat on poverty elimination and income distribution. Economists generally do not believe that zakat has an impact on macroeconomic variables, especially economic growth. The question is how zakat at a 2.5 percent rate can influence economic growth? This research will examine how zakat distribution can influence macroeconomics, especially economic growth, consumption, and investment.

Zakat highly implies on micro and macro-economic variables. In the past, zakat affected more on saving and investment behaviors of individuals without affecting the work efforts. The macro-economic effects are expected to include several dimensions including allocative efficiency, economic growth, distribution of income and wealth, poverty eradication, social security and stabilization (Haq, 2013).

Some writers argue that the collection and distribution of zakat will contribute to micro and macroeconomy, such as consumption, income distribution, economic growth. etc. See (Haq, 2013; Imtiazi, Mannan, Niaz, \& Deria, 2000; Mannan, 2000; Iqbal, 1985; Hasan, 2017). Zakah has important economic implications such as aggregate consumption, national saving, investment and aggregate production. In the Islamic Economy where zakat is applied, the society will break into two income groups: the payer and the recipient of zakat. The obligatory group of zakat (Muzakki) will transfer a certain proportion of their 
opinion to a group of people receiving zakat (mustahik). It will obviously increase the revenue from mustahik. The increase of the income will increase the consumption and simultaneously allow the mustahik to start forming savings over the long term.

Zakat will increase the consumption of basic goods and services and will change the use of luxury goods and services to the staple ones. The distribution of zakat to the poor and the needy leads to the increase of their income due to the low level of their wealth and income. The income and share of the zakat may be used for the consumption of essential goods. On the other hand, zakat will reduce the wealth and income of the rich. The loss of the rich's wealth and income may reduce the consumption of luxury goods and services (Siddiqi, 198I).

Several studies show that zakat can reduce the poverty gap, income gap, and poverty level. Patmawati says that zakat, in Selangor Malaysia, successfully reduces poverty (Patmawati, 2007; Eko Suprayitno, Radiah Abdul Kader, Azhar Harun, 2013; Suprayitno, Aslam, \& Harun, 2017). The result of the research in Malaysia shows that the zakah has an impact on the average consumption, but the impact is very small although theoretically states that the consumption tendency of mustahik is greater than muzakki. The small impact of the distribution of zakah on consumption may be affected by the use of data on the aggregate consumption of Muslims and non-Muslims, while the collected zakat are distributed to meet the needs of Muslims only.

The study only analyzes the effect of zakat on consumption directly, while zakat also has an indirect effect on the consumption through income. Productive Zakat distributed thorough business capital will increase capital production in mustahik business activities to increase the output and income of mustahik. Ultimately, the increase in income will increase household consumption of mustahik. Pambudi argues that the earning of zakat from BAZNAS of Kebumen shows that productive zakat has a significant effect on income, consumption, savings, and the infak of mustahik (Pambudi, 2013). Zakat can maximize the quality of Human Resources (HR) through the provision of facilities and infrastructure for the community, the increase of productivity, and income improve of society in general. If zakat is well and transparently managed, it will increase the welfare of the people, increase the work, and become a means of distribution of the economy of society.

Furthermore, the rich tend to relatively consume unimportant goods and services. As income increases, consumption patterns shift from primary goods and services and utility-based to the quality of life. Zakat also has important implications for saving. The theory of economy postulates that saving is the difference among incomes after consumption, in determining the income allocated for current consumption and how much is saved for future consumption. The current consumption level and the saving rate will be determined by adjusting the time preference rate and the interest rate. The interest rate will affect the current level of consumption through its relationship with savings (Eko Suprayitno, Radiah Abdul Kader, Azhar Harun, 2013; Hasan, 20I7; Mohammed Yusoff, 20I4; Shaikh \& Ismail, 20I7; Suprayitno, Abdul Kader, \& Harun, 20I3; Suprayitno et al., 2017; M. Yusoff, 20I4; M. B. Yusoff, 20II; Abdelbaki, 2015).

According to Islam, saving is not a residual activity, but a rational action with certain positive purpose, not to be stockpiled or used to speculate. Savings for future preparation are allowed even recommended. At the same time, Islam prohibits exaggeration.

In macro terms, the implementation of zakat will have a positive impact on the national saving rate. Since zakat is also imposed on accumulated wealth, not merely on income, the payment of zakat will encourage muzakki to increase the saving ratio to prevent the level of wealth declining. Meanwhile, as the taxation system of zakat is a friendly tax system to the business world, it will have a positive impact on aggregate production. Zakat has a low tariff and fixed and never changing because it is set in Shariah (Abdelbaki, 2015; Abu Bakar \& Rashid, 2010; Eko Suprayitno, Radiah Abdul Kader, Azhar Harun, 2013; Haq, 2013; Hasan, 2017; Imtiazi et al., 2000; Iqbal, I985; Mannan, 2000; Mohammed Yusoff, 20I4; Samad et al., 2016; Shaikh \& Ismail, 20I7; Siddiqi, I981; E ko Suprayitno \& Hasan, 2016; Eko Suprayitno et al., 2017; M. Yusoff, 2014; M. B. Yusoff, 201 I).

\section{Methodology \\ 2.I. Data Source}

Data obtained from Government Financial Statistics, International Financial Statistic (IFS), Badan Amil Zakat Nasional (BAZNAS), Central Bank of Indonesia (BI), Statistic Indonesia (BPS), and such reports which may be applied as reference.

The data collected is Consumer Prices Index, (CPI) for goods and basic service, the other government revenue and other consumption of government, Small and Medium Enterprises (SMES), public consumption, Real Production Aggregate, total government revenue, prices of basic need, individual income, collection and distribution of zakat.

\subsection{The Model}

The current research employs the Error Correction Model (ECM). According to Engle \& Granger (1987); (Muniroh, Ismail, \& Lazim, 2017), if a set of series $x t$ and yt are co-integrated, there exists a generating mechanism called Error Correction Model", which forces the variables to move closer over time whilst allowing a range of short-run dynamics. For example, if two variables $y t$ and $x t$ are co-integrated, which is $\sim \mathrm{CI}(\mathrm{I}, \mathrm{I})$, the general error correction model (ECM) can be written as: 


$$
\Delta y_{t}=\alpha_{0}+\varphi v_{t-1}+\sum_{j=1}^{J} \gamma_{j} \Delta y_{t-j}+\sum_{k=1}^{K} \sum_{j=1}^{J_{k}} \beta_{k j} \Delta x_{k(t-j)}+\varepsilon_{t}
$$

Where: $\Delta y_{t}=y_{t}-y_{t}-1, \Delta x_{t}=x_{t}-x_{t}-1, \varepsilon_{t} \sim$ iid $\left(0 . \sigma^{2} \varepsilon\right) \varphi$ necessarily negative and $v_{t}=\hat{\mathrm{y}}_{-} t-\left(\beta_{0}+\hat{\beta}_{1} t\right.$

The error correction model, however, is very powerful because it allows analysts to predict the short-term and long-term effects of variables on time series data. The standard way to derive the error correction model is to show that if $\mathrm{X}$ and $\mathrm{Y}$ are linear functions of a latent integrated process, the residuals of $\mathrm{Y}$ regressed on $\mathrm{X}$ should be stationary. This derivation of the error correction model starts with the assumption that both $\mathrm{Y}$ and $\mathrm{X}$ are integrated and demonstrates that the error correction model captures the equilibrium causal movements between these two co-integrated processes. Occasionally, however, some authors derive the error correction model from a different and more promising starting point (Davidson, Davidson, \& MacKinnon, 1995; Hall, Banerjee, Dolado, \& Galbraith, 1996; Holtz-Eakin, Newey, \& Rosen, 1988; Kapetanios, Shin, \& Snell, 2005; Persyn \& Westerlund, 2008; Westerlund, 2007). In this research, the error correction models is derived by (Eko Suprayitno, Radiah Abdul Kader, Azhar Harun, 2013; M. B. Yusoff, 20I I) with any alteration to Malaysian Economic. The model is:

From the basic model in equation (I), we can obtain the error correction model as follow:

The long term ECM model is derived by:

$L Y_{t_{t}}={ }_{a o}+{ }_{a I} L Y d_{i t}+a_{2} L C_{t}+{ }_{a 3} L Z k t_{t}+{ }_{a 4} L Z k t_{t-I}+{ }_{a s} L I_{t}+\mu I_{t}$

$\mathrm{LYd}=\log (\mathrm{Yd})$

$\mathrm{LGE}=\log (\mathrm{GE})$

$\mathrm{LZkt}=\log (\mathrm{zkt})$

$\mathrm{LZkt}_{\mathrm{t}-\mathrm{I}}=\log \left(\mathrm{Zkt}_{\mathrm{t}-\mathrm{I}}\right)$

From the basic model in equation (5), we can obtained the error correction model is:

$\mathrm{DYr}_{\mathrm{t}}=\alpha_{0}+\alpha_{I} D L Y d_{t}+\alpha_{2} D L G E_{t}+\alpha_{3} D L Z k_{t}+\alpha_{t} D L Z k_{t-I}+\alpha_{5} L y d(-I)_{t}+\alpha_{6} L G E(-I)_{t}+\alpha_{>} L Z k(-I)_{t}+\alpha_{8} L Z k(-I)_{t-I}$

$+\alpha_{9} \operatorname{ect}(-\mathrm{I})+\alpha_{10} \mu_{t}$

Where:

$\operatorname{DLYd}_{\mathrm{t}}=\operatorname{LYd}_{\mathrm{t}}-\operatorname{LYd}_{\mathrm{t}}(-\mathrm{I})$

$\mathrm{DLC}_{\mathrm{t}}=\mathrm{LC}_{\mathrm{t}}-\mathrm{LC}_{\mathrm{t}}(-\mathrm{I})$

$\operatorname{DLGE}_{\mathrm{t}}=\mathrm{LGE}_{\mathrm{t}}-\mathrm{LGE}_{\mathrm{t}}(-\mathrm{I})$

$D L Z k_{\mathrm{t}}=\mathrm{LZk}_{\mathrm{t}}-\mathrm{LZk}_{\mathrm{t}}(-\mathrm{I})$

$\mathrm{DLZkt}_{\mathrm{t}-\mathrm{I}}=\mathrm{LZk}_{\mathrm{t}-\mathrm{I}}-\mathrm{LZk}_{\mathrm{t}-\mathrm{I}}(-\mathrm{I})$

$\mathrm{Ect}=\mathrm{LYd}_{\mathrm{t}}+\mathrm{LC}_{\mathrm{t}}+\mathrm{LGE}_{\mathrm{t}}+\mathrm{LZk}_{\mathrm{t}}+\mathrm{LZk}_{\mathrm{t}-\mathrm{I}}+\mathrm{LI}_{\mathrm{t}}-\mathrm{LY}$

The long term ECM model is derived by:

$L Y_{t_{t}}=\beta_{o}+\beta_{I} L Y d_{i_{t}}+\beta_{2} L G E_{t}+\beta_{3} L Z k t_{t}+\beta_{4} L Z k t_{t-I}+\beta_{5} L I_{t}$

\subsection{Empirical Implementation of The Model}

\subsection{Stationarity Test}

The test of stationarity in the current research will apply the Dickey Fuller Unit Root test. The result of the test on the variables of the equation can be summarized in table I. The output analysis shows that the estimation of the variables have different integration. In table $\mathrm{I}$, we can explain that the $\mathrm{Yr}$ is significant at $\alpha=5$ percent and in the second-level difference (2 $2^{\text {nd }}$ differences) and $\mathrm{Z}$ is significant at $\alpha=\mathrm{I}$ percent the second-level difference, $\mathrm{Yd}$ is significant at $\alpha=\mathrm{I}$ percent and in level 
sencod difference ( $2^{\text {nd }}$ differences) and GE is significant at $\alpha=\mathrm{I}$ percent at level second difference. Thus, the variables are significant at $2^{\text {nd }}$ difference of test for unit root.

Table I. The Stasioneritity test Yr, Z

\begin{tabular}{ccccccccc}
\hline Lag & \multicolumn{2}{c}{ Yr } & \multicolumn{2}{c}{ Z } & \multicolumn{2}{c}{ GE } & \multicolumn{3}{c}{ Yd } \\
\hline & DF & ADF & DF & ADF & DF & ADF & DF & ADF \\
\hline$(-2)$ & $-2.325^{* *}$ & $-2.388^{* *}$ & $-4.4 I^{*}$ & $-4.106^{* *}$ & $-3.67^{*}$ & $-3.58^{*}$ & $-3.81^{* *}$ & $-3.61^{*}$ \\
\hline$(-1)$ & 1.03 & 1.15 & 2.559 & 2.388 & 1.05 & 1.21 & 1.59 & 1.65 \\
\hline
\end{tabular}

Source: Output Analyze Data,

*

\subsubsection{Error Correction Models Analysis}

The Analysis of Error Correction Model is conducted to see the impact of zakat on long-term economic growth. This analysis reveals the input of the deviation in the long term and short term dynamics. This model, short term dynamic is the input of the first difference, and the long term adjustment is done by the input of the error correction.

The result of the ECM in table 2 shows that the coefficient of error correction term lag one or ECT (-I) in the model is significant. The fact that the significance of the coefficient of ECT is -I means that among the economic growths, public consumption, small-medium enterprises investment, inflation, government expenditure, disposable income, collected zakat, and collected zakat years before (the distribution zakat), have co-integration, the correct specification model, the correct theory, and any causality relationships (at least there is one way relationship). Thus, there is no reason to refuse ECM model.

Table 2. Result the ECM Model

\begin{tabular}{crrr}
\hline Variable & Coefficient & t-Statistic & Prob. \\
\hline C & II2.2353 & $2.63 \mathrm{I} 2 \mathrm{II}$ & 0.0305 \\
\hline DLNZ & 0.470120 & 2.842354 & 0.1027 \\
\hline DLNYr & 3.679432 & 0.108976 & 0.9564 \\
\hline DLNGE & $-3.31084 \mathrm{I}$ & $0.7109 \mathrm{II}$ & -0.8919 \\
\hline DLNYd & 4.597410 & 0.803573 & 0.8669 \\
\hline BLZ & $0.44530 \mathrm{I}$ & 2.987159 & 0.0278 \\
\hline BLYr & 10I.258I & 2.768509 & 0.0212 \\
\hline BLGE & 54.16133 & 2.781265 & $0.020 \mathrm{I}$ \\
\hline BLYd & 26.36338 & 2.745809 & $0.025 \mathrm{I}$ \\
\hline ECT(-I) & 0.856415 & 3.612152 & 0.0072 \\
\hline R-squared & & & \\
Adjusted R-squared & 0.9964950 & & \\
& & & \\
\hline
\end{tabular}

The variable of the first difference shows that it is significant at $\alpha=\mathrm{I} \%$ is ECT (-I), significant at $\alpha=\mathrm{I} \%$ is $\mathrm{C}$, $\mathrm{Zk}$, and significant at $\alpha=5 \%$. Besides, all the variables show a close relationship among one another, and it is significant at $\alpha$ $=5 \%$. The variable in the first difference shows the short term influence. The variable of the first different levels like BLZ and BLYr shows influence in the long-term.

The value of the coefficient of determination $\left(R^{2}\right)$ is 0.996495 which shows that the variation of economic growth can be explained by public consumption, small-medium enterprise investment, inflation, government expenditure, disposable income, collected zakat, and collected zakat years before (the distribution of zakat). The fact that it is equal to 99.65 percent and 0.35 percent is explained by the other variables outside the model. The influence of independent variables in the simultaneous model is significant at $\alpha=\mathrm{I} \%$. Table 2 explains the short term and long term influence or impact of zakat distribution towards economic growth. 
Table 3. The Influence of Independent Variable on the Dependent one in the short and the long term

\begin{tabular}{|c|c|c|}
\hline Independent Variables & Short Term & Long Term \\
\hline LZk & I.638422 & 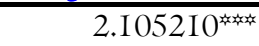 \\
\hline$L Y d$ & $2.584804^{4}$ & 2.248918 \\
\hline
\end{tabular}

\section{Source: Output Analyze Data}

significant at $\alpha=$ I percent, 5 percent and I0 percent.

Short term: effect shock without lag in the observation period

Long term: the equilibrium effect aftershock in the next period (from old equilibrium to the new equilibrium)

Zakah distributed for consumptive assistance has been able to provide a significant multiplier effect. If it is given for productive assistance such as venture capital or revolving funds, it will certainly produce a more multiplier effect which may increase the economy. Zakat for productive assistance gives a greater effect than zakat for consumptive assistance (Hafidhuddin, 20I I; Mohamad Soleh Nurzaman, 20I0; Samad et al,, 2016). Zakat is channeled to people in need will have a greater effect on aggregate demand because the consumption needs of this group are relatively larger. However, the strategic role of zakat will be realized if the Muslims believe and perform zakat properly. In addition, it implants a strong conviction about the importance of zakat obligations to establish vertical relationship with Allah SWT and to achieve welfare fairly in community life (Abdelbaki, 2015; Imtiazi et al., 2000; Mannan, 2000; Mohamad Soleh Nurzaman, 2010; Sofiah Mohamed, Kamarul Azmi Jasmi, \& Muhammad Azhar Zailaini, 2016; E ko Suprayitno \& Hasan, 2016; Eko Suprayitno et al., 2017; M. Yusoff, 20I4; M. B. Yusoff, 20II).

The above explanation concludes that zakat hasan plays an important role in the economy, in both micro and macro. It can be consumptive and productive assistance for muzakki and muztahik. Zakat in a systematic and organized model is able to provide a great effect to increase the national income of a country due to the acceleration of money circulation. That zakat can lead to the multiplication of economic development is explained as follow:

Zakat for consumptive aid given to mustahik may increase the income of mustahik, which means the purchasing power of mustahik on a product can increase as well. The increasing purchasing power of a product will impact on increasing demand for a product. The increase in demand is in line with an increase in the production of a company. The impact of the increased production is the addition of production capacity, which means the company will absorb more labor and the unemployment rate will decrease. Moreover, the increase in production will result in an increase in taxes paid to the state, either corporate tax, valueadded tax, or income tax.

If the state revenue from the taxes increases, the state will be able to provide facilities and infrastructure for development, and it can provide public facilities for the community. If zakat can be significantly collected, it can provide free investment and health for the community. The above descriptions shows that zakah payments can produce a multiplier effect in an economic language known as the multiplier effect in the economy, which in the end will indirectly also impact us. Assistance given for consumptive action can provide a significant multiplier effect. Zakat is given trough productive assistance such as working capital or revolving funds, The multiplier effect will be gained even greater in an economy because it gives more, or twice as much as zakat in the form of consumptive assistance (Abdelbaki, 20I5; Sofiah Mohamed et al., 20I6; Eko Suprayitno et al., 2017; M. Yusoff, 2014; M. B. Yusoff, 2011).

\section{Conclusion}

Muslims are subject to pay zakat if they can afford it, based on the criteria in Shariah. It is also important for a Muslim to pay tax since both zakat and tax could develop the nation. The fact that the administration of zakat is under the authority of every state causes differences in zakat practice among states in Malaysia. Every state has differences in policy and administration of zakat because each has a different problem. It will lead to different implications, and every state has its own way to make the most of it because they know the condition more. Thus, the administration of religious obligatory can be more optimal.

The result of the analysis shows that zakat in Malaysia plays an important role in economic growth, consumption, and investment. The other result of the analysis on OLS reveals that zakat has a positive influence on economic growth. Zakat affects consumption and investment. The value of the influence of zakat on economic growth is 0.0932 , on consumption is 4.406, and investment is 0.186 (small-medium enterprises).

ECM analysis shows that zakat will influence economic growth, either in the short term or long term. Therefore, the management of zakat in Malaysia can be made an example for the same nations in Malaysia where zakat can be applied to individual reduced income tax. Besides, the shelf distribution system of zakat which is more improved especially the investment and legal capital helps open greater unemployment in Malaysia. The distribution of zakat for financial costs like personal capital, 
capital for small and medium enterprises, and training for unemployment have made a short term and long-term effect on economic growth and multiplier effect.

\section{References}

Abdelbaki, H. H. (2015). The Impact of Zakat on Income Inequality and Poverty in Malaysia: A Panel Data Analysis. Review of Integrative Business and Economics Research.

Abu Bakar, N. B., \& Rashid, H. M. A. (2010). Motivations of Paying Zakat on Income: Evidence from Malaysia. International Journal of Economics and Finance. https://doi.org/I0.5539/ijef.v2n3p76

Davidson, J., Davidson, R., \& MacKinnon, J. G. (1995). Estimation and Inference in Econometrics. Economica. https://doi.org/I0.2307/2554780

Eko Suprayitno, Radiah Abdul Kader, Azhar Harun. (2013). The Impact of Zakat on Aggregate Consumption in Malaysia. Journal of Islamic Economics, Banking and Finance,

Hafidhuddin, D. (20II). Peran Strategis Organisasi Zakat Dalam Menguatkan Zakat Di Dunia (The Strategic Role of Zakat Organization in Strengthening Zakah in the World). Jurnal Ekonomi Islam Al-Infaq.

Hall, A., Banerjee, A., Dolado, J. J., \& Galbraith, J. W. (1996). Co-Integration, Error Correction, and the Econometric Analysis of Non- Stationary Data. The Economic Journal. https://doi.org/I0.2307/2235236

Haq, S. G. (2013). Distribution of income and wealth in islam. South East Asia Journal of Contemporary Business, Economics and Law.

Hasan, Z. (2017). Consumprion and Islam: Micro Foundations and Macro Modelling. Journal of Economic and Social Thought, 4(I), I08-I I8. https://doi.org/IO.I453/jest.v4iI.I207

HASAN, Z., \& HASAN, Z. (20I7). Consumprion and Islam: Micro Foundations and Macro Modelling. Journal of Economic and Social Thought, 4(I), I08-I I8. https://doi.org/I0.I453/jest.v4iI.I207

Holtz-Eakin, D., Newey, W., \& Rosen, H. S. (1988). Estimating Vector Autoregressions with Panel Data. Econometrica. https://doi.org/I0.2307/I913103

Imtiazi, I. A., Mannan, M. A., Niaz, M. A., \& Deria, A. H. (2000). Management of Zakah in Modern Muslim Society. In Islamic Research and Training Institute, Islamic Development Bank.

Iqbal, M. (1985). Zakah, Moderation and Aggregate Consumption in an Islamic Economy. Journal of King Abdulaziz University: Islamic Economics.

Kapetanios, G., Shin, Y., \& Snell, A. (2005). Testing for Cointegration in Nonlinear STAR Error Correction Models. SSRN Electronic Journal. https://doi.org/I0.2139/ssrn.428602

Keputusan Direktur Jenderal Pajak Nomor KEP-I63/PJ/2003 tentang Perlakuan Zakat Atas Penghasilan Dalam Penghitungan Penghasilan Kena Pajak Pajak Penghasilan, article I (s I and 3).

Mannan, M. . (2000). Effects of Zakah Assessment and Collection on the Redistribution of Income in Contemporary Muslim Countries. IR TI-IDB.

Mohamad Soleh Nurzaman. (2010). Zakat and Human Development: An Empirical Analysis on Poverty Alleviation in Jakarta , Indonesia I. 8th International Conference on Islamic Economics and Finance.

Mohammed Yusoff. (2014). Zakat distribution, education, and real income per capita in Malaysia. 2014 International Multidisciplinary Academic Conference.

Muniroh, M. F., Ismail, N., \& Lazim, M. A. (2017). Combination of forecasts with an application to unemployment rate. Pertanika Journal of Science and Technology.

Pambudi, H. A. (20I3). PERANAN ZAKAT PRODUKTIF DALAM PEMBERDAYAAN MASYARAKAT MISKIN (Studi kasus pada Badan Amil Zakat (BAZ) Kabupaten Kebumen). Fokus Bisnis.

Persyn, D., \& Westerlund, J. (2008). Error-correction-based cointegration tests for panel data. Stata Journal.

Samad, M. N., Ariff, M., \& Nassir, A. M. (2016). Impact of zakat payment offset system on income tax collection in Malaysia. International Journal of Applied Business and Economic Research.

Shaikh, S. A., \& Ismail, A. G. (2017). The Role of Zakat in Sustainable Development Goals. International Journal of Zakat.

Shuaib, F. S., Kamal, M. H., Bustami, T. A., Othman, N., \& Sulaiman, M. S. (2017). Towards an apex Sharia court in Malaysia. Pertanika Journal of Social Sciences and Humanities.

Siddiqi, M. N. (I98I). I52672_07-MuslimEconomic.pdf.

Sofiah Mohamed, Kamarul Azmi Jasmi, \& Muhammad Azhar Zailaini. (2016). Elements of Delivering Islamic Education Through Islamic Morality in Several Malaysian Schools. Pertanika Journal of Social Sciences and Humanities.

Suprayitno, E ko, \& Hasan, M. A. G. (2016). Zakat and Economics Growth in the Peninsular Malaysia: An ARDL Bounds Testing Approach. International Journal of Social and Economic Research. https://doi.org/I0.5958/22496270.2016.00007.6

Suprayitno, Eko, Abdul Kader, R., \& Harun, A. (20I3). Zakat sebagai Pengurang Pajak dan Pengaruhnya terhadap Penerimaan 
Pajak di Semenanjung Malaysia. Inferensi. https://doi.org/I0.18326/infs13.v7iI.I-28

Suprayitno, Eko, Aslam, M., \& Harun, A. (2017). Zakat and SDGs : Impact Zakat on Human Development in the Five States of. International Journal of Zakat.

Undang-Undang No. 38/I999, article I4 (s 3).

Undang-Undang No. 7/2000, articles 4 (s 3), 9 (s I).

Westerlund, J. (2007). Testing for error correction in panel data. Oxford Bulletin of Economics and Statistics. https://doi.org/IO.I I I I/j.I468-0084.2007.00477.x

Yusoff, M. (20I4). Zakat distribution, education, and real income per capita in Malaysia. 20I4 International Multidisciplinary Academic Conference.

Yusoff, M. B. (201I). Zakat Expenditure, School Enrollment, and Economic Growth in Malaysia. International Journal of Business and Social Science. https://doi.org/I0.10I7/SI8764045I 1200046

\section{Copyrights}

Copyright for this article is retained by the author(s), with first publication rights granted to the journal. This is an open-access article distributed under the terms and conditions of the Creative Commons Attribution license (http://creativecommons.org/licenses/by/4.0/). 